\title{
HAYDEN WHITE ve TARIH ANLATISI SORUNU
}

\author{
Selim TEZCAN*
}

Öz Bu makale, Hayden White'ın tarih anlatısı konusunda Metahistory kitabı ve yarım yüzyılı aşan kariyeri boyunca yayınladığı makalelerde dile getirdiği düşünce ve gözlemleri ele almaktadır. White, "dilsel dönüş"ten hareketle anlatının salt tarihçinin bulgularını aktarmakta kullandığı bir araç olmakla kalmayıp beraberinde kendi içeriğini de getirdiğini ortaya koyan, böylece onu sorunsallaştıran ilk tarihçi olmuştur. Mevcut çalışma, onun tarih anlatısı ve sorunları hakkındaki irdelemelerini dört bölümde incelemektedir. İlk bölümde, White'ın başı sonu bellisiz bir takvimden vakayinameye ve oradan olay örgüsüne sahip tam bir tarih anlatısına uzanan değişik tarihyazımı türlerini nasıl karşılaştırdığını inceleyeceğiz. İkinci bölümde, White'ın tarih anlatısının olay örgüsünün ötesine geçen kurgusal yanlarına, yani temelindeki kavramsal mecazi çerçeveye, argüman kipine ve bunların ideolojik imalarına nasıl ışık tuttuğunu göreceğiz. Bunu izleyen bölümde, kurgunun tarih anlatısının harcındaki bu önemli yerini kabul etmenin; tarihin gerçeklikle ilişkisi, sağladığı bilgilerin doğası ve kurgu edebiyatla benzerlik ve farkları gibi önemli konular bakımından doğurduğu sonuçlar hakkında White'ın gözlemlerini ele alacağız. Dördüncü bölümde ise White'ın geleneksel haliyle tarih anlatısına yönelik eleştirileri üzerinde duracağız. Tarihsel olayları anlatılaştırmanın, gerçekliğe sahici olmayan bir tutarlılık, bütünlük ve ahenk katarak onu estetize etme, "ehlileştirme" sonucunu getirdiği ve bu bakımdan özellikle modern çağın Dünya Savaşları ve Yahudi Soykırımı gibi dehşet verici, anlamlandırılması güç olayları karşısında hem yetersiz hem de ahlaken sakıncalı kaldığı konusunda White'ın tespitlerine ve buna karşı sunduğu çözüme eğileceğiz. Sonsöz kısmında ise White'ın bizzat ele almadığı, ancak yaklaşımının verimli bir şekilde uygulanabileceği diğer bazı konulara işaret edeceğiz.

Anahtar Kelimeler: Hayden White, Tarih, Tarihyazımı, Anlatı, Dilsel Dönüş

\section{HAYDEN WHITE and the QUESTION of HISTORICAL NARRATIVE}

\begin{abstract}
This article aims to survey Hayden White's thoughts on the nature and uses of historical narrative. White has been the first historian to draw upon the linguistic turn to problematize historical narrative, emphasizing that it is not only an empty form used to communicate the results of research and analysis, but something that contributes its own content as well. The study is divided into four sections. In the first section, it dwells on White's comparative analysis of different forms
\end{abstract}

* Dr. Öğr. Üyesi, Ankara Sosyal Bilimler Üniversitesi, SBBF, Tarih Bölümü, E-posta: selimtez76@gmail.com 
of historiography extending from the annals to a chronicle and thence to a fully emplotted narrative. In the next section, it focuses on White's revelation of other fictive components of historical narrative, including the conceptual and figurative framework underlying it. In the third section, the study discusses White's comments on the implications of this fictive aspect of historical narrative for such issues as the links of history with past reality, the nature of the knowledge it produces, and its similarities with and differences from literary fiction. In the fourth section, it examines White's criticisms against traditional historical narrative. In particular, it focuses on his observation that narrativizing historical events leads to the aestheticization and domestication of past reality by providing it with a false coherence, integrity and completeness, and therefore proves inadequate and morally objectionable when faced with modernist events like the Holocaust. In the epilogue, the study suggests some other topics which, although not discussed by White himself, could be subjected to his line of analysis with fruitful results.

Keywords: Hayden White, History, Historiography, Linguistic Turn

\section{Extended Summary}

\section{Purpose}

This article aims to present a survey of Hayden White's thoughts on the nature and uses of historical narrative. White has been the first historian to draw upon the linguistic turn to problematize historical narrative, emphasizing that it is not only an empty form that can be used freely to communicate the results of research and analysis, but something that contributes its own content as well.

\section{Method}

The study is divided into four sections. In the first section, it dwells on White's comparative analysis of different forms of historiography extending from the annals to a chronicle and thence to a fully emplotted narrative. In the next section, it focuses on White's revelation of other fictive components of historical narrative, including the conceptual and figurative framework underlying it. In the third section, the study discusses White's comments on the implications of this fictive aspect of historical narrative for such issues as the links of history with past reality, the nature of the knowledge it produces, and its similarities with and differences from literary fiction. In the fourth section, it examines White's criticisms against traditional historical narrative. In particular, it focuses on his observation that narrativizing historical events leads to the aestheticization and domestication of past reality by providing it 
with a false coherence, integrity and completeness, and therefore proves inadequate and morally objectionable when faced with modernist events like the Holocaust. In the epilogue, the study suggests some other topics which, although not discussed by White himself, could be subjected to his line of analysis with fruitful results.

\section{Results and Discussion}

Comparing and contrasting annals, chronicles and full-fledged historical narratives, White shows that past events by themselves do not constitute stories with a definite beginning, development and end, waiting to be uncovered from the historical record. Their ordering in the form of a story, some of them constituting its beginning, some its middle, and some its end, is achieved through the historian's fictive operations, and in accordance with his outlook as the member of a certain social and political order. Moreover, historians make use of certain plot structures in turning a series of events into a narrative, choosing among the plot types offered by their culture and developed in its myths and literary fiction. White underlines that choosing one of the plot types found in Western culture, namely romance, tragedy, comedy and satire, and endowing the narrative with the characteristics peculiar to that type, is also a fictive, imaginative operation.

However, White's analysis of historical narrative reveals that its fictive aspects reach deeper than its plot structure endowed with a definite beginning and end. Since the objects of historical study are no longer observable, all historians have to prefigure the historical field, the objects (individuals, collectivities, events, institutions etc.) inhabiting it, and the particular sort of relationships obtaining among them. Moreover, history lacks a technical jargon with pre-assigned meanings, and relies on everyday language for its operations. For these reasons, in order to familiarize and make sense of the objects in the historical field, which are no longer visible and therefore alien, historians have to make use of the tropes of everyday language: metaphor, metonymy, synecdoche, and irony. White notes that the historian's selection among these tropes also impacts on his choice of plot, mode of argument and ideological implication. Moreover, historical facts, as distinct from historical events which have taken place in the past, are also constituted conceptually or figuratively by the historian, for he describes them beforehand in the way proper for their insertion into a certain plot structure.

Although White thus underlines the fictive and figurative operations involved in history writing, he does not deny the differences between history and fiction, nor the chances of the 
historian to uncover aspects of past reality through the use of historical records. Nevertheless, he stresses that because of the important share of fiction that goes into the making of a historical narrative, the latter is not an empty form that could be freely used to transmit information and arguments, but contributes its own content as well. It is not possible therefore to split historical discourse into a content that could be stripped of all its fictive and figurative paraphernalia and summarized in the form of factual information and logical arguments, on the one hand, and a linguistic outer form, ornamental at best, on the other.

White repeatedly draws attention to the negative social and political consequences involved in molding a series of past events into a narrative through fictional operations. He points out that narrativization inevitably produces an aesthetic illusion of coherence, completeness and integrity that is mythical in nature and does not correspond to the rough and rugged character of real events. The narrative's aestheticizing tendencies serve to mask those "sublime" aspects of historical reality that are astonishing, repugnant, and difficult to make sense of, thus helping secure conformance to the existing social and political order. They remain especially inadequate and morally objectionable when confronted with "modernist" events like the World Wars and the Holocaust. As a solution for this problem, White suggests trying some of the techniques developed in modern literature, techniques that would help historians narrate such events without having to narrativize them.

\section{Conclusion}

Although originally educated as a medievalist, White does not dwell on historiographical narratives written before the eighteenth century, except for his comments on annals, chronicles, and proper histories in a single article. His methodology seems applicable however to the historical narratives written in the period extending from the Antiquity to the Early Modern Age as well. With a comparative approach, it could also be applied to historical narratives produced outside Europe, inquiring among other issues into the kinds of tropes and plot structures they used. Finally, since White admits that research and writing proceed simultaneously, it would be worth investigating if the tropes and plots that begin to take shape in the historian's mind during his research has any impact on the way he reads and sifts evidence from historical documents. 


\section{Giriş}

Tarih anlatısı, salt bir zarf mıdır? Yoksa aynı zamanda mazruf mudur? Hayden White'ın kariyerinin çoğu bu soruyu irdelemekle geçmiştir. 19. yüzyılda kurumlaşan "bilimsel" tarihçilik anlayışı uyarınca, tarihçi bir kez arşiv kayıtlarındaki verileri bulup analiz ettikten, olayların kronolojisini saptadıktan ve aralarındaki neden-sonuç ilişkilerini analiz ettikten sonra tek yapması gereken şey, bu yolla keşfettiği geçmişte yaşanmış hikâyeleri anlatı formunda okurlarına aktarmaktı. Bu aktarım daha ustaca veya acemice yapılabilirdi, ancak o nihayetinde çalışmanın "bilimsel" içeriğini etkilemeyen, salt retorik ve süsleme niteliğinde bir işti (Domanska v.d., 1994: 97). Bunun böyle olmadığını, bulgularını anlatı formuna sokarken tarihçinin hayalgücünü ve içinde yetiştiği kültürün sağladığı anlatı formlarını kullanarak yaratıcı nitelikte bir iş gerçekleştirdiğini, anlatı haline getirme esnasında yaptığı tercihlerin tarihsel olayları kronoloji ve neden-sonuç analizlerinin sağladığı açıklamaların ötesinde bir anlamla da donattığını, onlara dolaylı bir yorum kattığını açıklıkla ilk defa Hayden White ortaya koyacaktı. White'ın söylediği gibi, tarih anlatısı salt bilimsel içeriği gösteren saydam bir pencere veya tarihsel olaylara karşılık gelen bir model değildi; kendisi de bizzat hayalgücünün yardımıyla ortaya çıkan sözel bir imge, söylemsel bir "şey"di ve işaret ettiği şeylere, yani geçmişteki olaylara ve aralarındaki bağlara ışık tuttuğu kadar okurla aralarına girip algılanmalarını zorlaştırması da söz konusuydu (White, 1999a: 6). Her ne kadar White'tan önce Saussure, Barthes ve Derrida gibi düşünürler "dilsel dönüş"ü (linguistic turn) tarih teorisine uygulamaya başlamışlar ise de White bu tespitleriyle 1960 'lar ve 70'lerdeki dilsel dönüşün tarihyazımı alanındaki başlıca temsilcisi olarak boy gösteriyor, bir tarihçi olarak tarihçilere seslendiği için çok daha yankı uyandırıyor ve tarih ile kurgu arasında bulunduğu varsayılan uçurumun anlatı teorisi yoluyla aşılmasında kritik bir rol oynuyordu. Yeni Eleştiri (New Criticism) akımının yazarın ve metnin niyetliliği (intentionality) arasında yaptığı ayrımdan esinlenen White, anlatının tarihçinin niyetlerinden bağımsız olarak kendi içeriğini de beraberinde getiren bir unsur olduğunu ortaya koyuyor, onu sorunsallaştırıyordu (Ankersmit, 1998: 185; Ankersmit, 2009: 77; Partner, 1998: 170-71).

Mevcut çalışmada, White'ın tarihteki bu anlatı sorununu nasıl ele aldığını, Metahistory kitabından ve çok sayıda makalesinden hareketle ışık tutmaya çalışacağız. Çalışma dört bölüme ayrılmaktadır. İlk bölümde, White'ın başı sonu bellisiz bir takvimden vakayinameye ve oradan 
olay örgüsüne sahip tam bir tarih anlatısına uzanan değişik tarihyazımı türlerini nasıl karşılaştırdığını inceleyeceğiz. İkinci bölümde, White'ın tarih anlatısının olay örgüsünün ötesine geçen kurgusal yanlarına, yani temelindeki kavramsal mecazi çerçeveye, argüman kipine ve bunların ideolojik imalarına nasıl ışık tuttuğunu göreceğiz. Bunu izleyen bölümde, kurgunun tarih anlatısının harcındaki bu önemli yerini kabul etmenin; tarihin gerçeklikle ilişkisi, sağladığı bilgilerin doğası ve kurgu edebiyatla benzerlik ve farkları gibi önemli konular bakımından doğurduğu sonuçlar hakkında White'ın gözlemlerini ele alacağız. Dördüncü bölümde ise White'ın geleneksel haliyle tarih anlatısına yönelik eleştirileri üzerinde duracağı. Tarihsel olayları anlatılaştırmanın, gerçekliğe sahici olmayan bir tutarlılık, bütünlük ve ahenk katarak onu estetize etme, "ehlileştirme" sonucunu da getirdiği ve bu bakımdan özellikle modern çağın Dünya Savaşları ve Yahudi Soykırımı gibi dehşet verici, anlamlandırılması güç olayları karşısında hem yetersiz hem ahlaken sakıncalı kaldığı konusunda White'ın tespitlerine ve sunduğu çözüme eğileceğiz. Son Söz kısmında ise White'ın bizzat ele almadığı, ancak yaklaşımının verimli bir şekilde uygulanabileceği diğer bazı konulara işaret edeceğiz.

\section{Takvimden Vekayıname ve Anlatıya}

White, değişik tarihyazımı biçimleri üzerinde dururken yılları ve yanlarında olayları kaydetmekle yetinen bir takvimden (annals) başlangıcı ve gelişmeye sahip, ancak sonuçtan yoksun bir vakayinameye (chronicle) ve oradan da başlayıp gelişen ve biten tam teşekküllü bir tarih anlatısına giden yolu inceler. Ancak tarihyazımını inceleyenlerin yaptığı gibi bunları salt anlatının evrim çizgisi üzerindeki duraklar olarak değil, aynı zamanda tarihsel gerçeklik hakkındaki alternatif kavrayışların ürünleri olarak da görür (White, 1987a: 5-6). Bir tarihsel olaylar dizisinin bir anlatı teşkil etmesi için başlangıç, gelişme ve sonuç noktalarına ihtiyaç vardır. Oysa gerçeklikteki olaylar birbirini izleyerek akıp gitmektedir, hangi kritere göre bu noktalar seçilecektir? White, söz konusu kriterlerin mantıki değil ancak ahlaki olabileceklerine ve sosyo-politik bir merkezin, yani bir otoritenin ve bunun ortaya koyduğu hukuki bir düzenin varlığına ihtiyaç gösterdiklerine dikkat çeker. White'ın takvim örneği olarak incelediği, Erken Ortaçağ'da, Galya'da kaleme alınmış St. Gall takviminde çoğu yılların yanına olay bile yazılmamıştır; buradaki tek devamlılık öğesi, milattan beri süregelen "tanrının yılları"dır (Anni Domini). Kıtlık, don ve sel gibi doğal felaketlerle İspanya Müslümanlarının Galya'ya geçerek Frank bölgesinin içine yaptıkları akınlar gibi insanların dünyasına ait olaylar arasında bir ayrım yapılmaz. Yazar ilahi otoritenin dışında, belli bir topluluğa özgü bir sosyo-politik merkezin ve 
ona ait bir hukuki düzenin şuuruyla yazmadığı, ortada merkezi bir özne olmadığı için ikinci tür olaylara da ilki gibi salt "başa gelen" bir şey muamelesi yapar; bunların yazar tarafından olmaması gereken, ahlak veya adalete aykırı bir hadise olarak görüldüklerine dair hiçbir kanıt yoktur. Ayrıca kaydedilen olayların neye göre seçildikleri veya dışarıda bırakıldığı da belli değildir; 732'de Franklar ile Müslümanlar arasında gerçekleşen Poitiers Savaşı kaydedilirken yine aynı yıl çıkan Tours Savaşı'ndan bahsedilmez. En önemlisi, bu takvimde gerçek bir baş, orta veya sonuç noktası da yoktur. Başladığı gibi ansızın biter. Arada kaydedilen olayları birbirine bir "gelişme çizgisi" veya nedensellikle bağlamaya yönelik hiçbir girişim yoktur (White, 1987a: 6-15).

White, tarih anlatısının bir sonraki gelişim safhası olarak Reims'lı Richerus'un 10. yüzyıl sonundan kalma Historiae başlıklı vakayinamesini ele alır. Burada artık bir başlangıç noktası mevcuttur; eser dünyanın yaradılışından başlar. Yazarın bağlı olduğu otorite de Reims Başpiskoposu Gerbert d'Aurillac'ın şahsında, yararlandığı klasik yazarlarda ve Reims'da selefi olan vakanüvisin eserinde temsil edilmektedir. Vakayiname, bu formun özelliği uyarınca birbiriyle bağıntısız bir olaylar dizisini alt alta sıralamakla kalmaz; ana izleği, Reims manastırında keşiş olan yazarın açıkça tarafını tuttuğu Gerbert ile rakip bir Başpiskopos adayı arasındaki mücadeledir. Yine vakayiname formu uyarınca olaylar sadece kısaca kaydedilmekle kalmaz, daha detaylı işlenir ve birbirleriyle ilişkilendirilir; hikâyeler anlatmaya doğru bir yöneliş mevuttur. Ancak yıllara göre düzenlenmiş kronolojik çerçevenin dışına çıkılmaz (yine de kimi vakayinamelerde olaylar belli başlıklar veya hüküm süreleri altında gruplanabilmektedir). Bu nedenle, başlangıç ve gelişmenin mevcudiyetine karşın tüm vakayinamelerde olduğu gibi bunda da hikâyenin gerçek bir son noktası, bitişi yoktur ve Gerbert'in kaçıp papa tarafından rakibinin atanmasıyla vakayiname sona erer. Bu olayın hikâye için gerçek bir bitiş teşkil etmemesi; yazarın onun adil veya gayrı adil bir sonuç olduğuna dair yargıda bulunmasına elverecek bir ilkeye sahip olmamasından kaynaklanmaktadır White'a göre (White, 1987a: 520).

White'ın tam teşekküllü bir tarih anlatısına örnek olarak incelediği Floransalı Dino Compagni'nin Cronica adlı eserindeyse başlangıç ve gelişme de, bitiş de vardır. Eserin konusu, Floransa'daki Guelph Partisinin içinde bulunan papa taraftarı Siyah ve karşıtı Beyaz hizipler arasındaki çekişmedir. Siyah Hizip kazanarak aralarında Dante'nin de olduğu Beyaz Hizip üyelerini şehirden sürmüş, Dino da bu arada tüm kamu görevlerinden men edilmiştir. Buradaki 
ahlaki otorite kaynağı, yazarın üyesi olduğu Beyaz hizip mensubu Floransalılardır. Dino olayları birbirine bağlayarak çatışmanın hikâyesini anlatır, neden ve sonuçlarını analiz eder. Eseri, diğer kamptan Floransalıların yaptığı kötülükleri sayıp döken, ardından da Fransız Kralı VII. Henry’nin gelip onları cezalandıracağı ve ortadaki adaletsizliği düzelteceği kehanetinde bulunan bir pasajla sona erer. Burada hikâyenin başını Dino'nun üyesi olduğu gruba haksızlık yapılması, bitişini de yakında bu haksızlığın düzeltilecek olduğu yolundaki ahlaki içerikli yargısı teşkil eder (White, 1987a: 22-23).

White, bu gözlemlere dayanarak tarih anlatısının şekillenmesini sağlayacak başlangıç, gelişme ve sonuç noktalarının da tarihsel olayların akışı içinden kendiliğinden ortaya çıkmayacağını ve belirlenmelerinin tarihçinin seçimine bağlı olduğunu vurgular. Dolayısıyla aynı olayı, diyelim bir hükümdarın taç giyişini bir tarihçi anlatısının başlangıcı olarak seçerken bir diğeri onu anlatıyı geliştirirken kullandığı bir geçiş motifi, diğeri de sonucu olarak seçebilir. Bu seçimlere göre aynı dönemin tarih anlatıları birbirinden çok farklı anlam ve mesajlara sahip olabilir (White, 2014d: 5-6). White, başta değindiğimiz gibi tüm bu seçimlerin nihayetinde ancak ahlaki nitelikte bir seçim olabileceğini belirtir. Çünkü eğer yazarın zihninde insanların bu dünyada kurduğu bir sosyo-politik merkez ve ona özgü bir hukuki düzen, bunların teşkil ettiği merkezi bir özne yoksa tek tanınan otorite Tanrıysa, Galya'ya yapılan Arap akınları gibi olaylar tıpkı sel ve kıtlıklar gibi takdir-i ilahi olarak algılanıp geçileceklerdir. Ancak yazar bir insan topluluğuna ait hukuki düzenin ve bundan kaynaklanan otoritenin şuurundaysa bu tür olaylar düzenin ihlali olarak algılanabilir ve hikâye konusu olabilecek bir çatışma doğabilir. Böyle bir hikâyenin başlangıç noktasını söz konusu düzeni ihlal eden bir durumun ortaya çıkması, devamını bundan kaynaklanan çatışmanın gelişmesi, sonuç noktasını da bu çatışmanın bir şekilde (adaletin yerine gelmesi, karşı tarafın kazanması, uzlaşma vb.) çözüme bağlanması oluşturacaktır. Böylece gerçekliğin kesintisiz akışından ayrılarak bir hikâyenin bitip diğerinin başlatılabilmesi için belli bir siyasi ve toplumsal kampın açısından ahlaki bir gerekçeye ihtiyaç duyulduğu meydana çıkmaktadır. Tarih anlatısının başından sonuna ahenkli ve tutarlı bir şekilde gelişen bir hikâye olarak biçimlendirilmesinin geri planında böylece ahlaki bir moment gizlenmekte; etik, estetik kisvesine bürünmektedir (White, 1987a: 11-25).

Bu nedenle, White'ın ısrarla vurguladığı gibi, geçmiş olaylar bize kendiliğinden hikâyeler halinde "malum" olmaz veya tarihçi tarafından keşfedilmezler; onları kiminin başını, kiminin ortasını, kiminin sonunu teşkil ettiği hikâyeler şeklinde düzenlemek, tarihçinin yaratıcı 
işlemlerinin ürünü ve belli bir siyasi-toplumsal örgütlenmenin üyesi olarak verdiği ahlaki hükümlerin sonucudur (White, 2014d: 6). White'ın bu gözlemlerinin ima ettiği ironik sonuç, çıplak gerçekliği en yakından aksettiren tarih türünün, çağımızın en gelişken tarih anlatıları değil de St Gall gibi bir Erken Ortaçağ takvimi çıkmasıdır. Çünkü olaylara bir baş, orta veya son biçmeye yeltenmeyen ve zamanın akışı içindeki doğal veya insani her türlü olayı aynı kayıtsızlıkla listeleyen bu biçim, tarihçinin yaratısı, seçimleri ve hayalgücüyle yaptığı katkı ve çarpıtmalardan en uzak olanıdır aynı zamanda (White, 1987a: 24-25; Partner, 1998: 165-66).

Tarihçinin kullandığı yaratıcı inisiyatif, sadece anlatının başını, ortasını ve sonunu teşkil edecek olayları belirlemekle de sınırlı değildir White'a göre. Olayların tarih sırasına göre bir dizisini oluşturduktan sonra bunların arasında seçki yaparak, kimilerini ön plana çıkartıp onlara diğer olayların nedeni veya önemli bir hikâye unsuru vasfıyla kilit bir rol biçerek, diğerlerini geri plana iterek veya tümden görmezden gelerek, icabında kronolojik değil farklı bir sırayla bahsederek onları anlatıya dönüştürür. Tabi bu arada da gerçekliği yine belli bir oranda çarpıtmış olur (White, 1985e: 111-12). White bu işlemlere soyut bir örnek de getirir. Onun örneği üzerinden ilerleyerek diyelim ki belgelerden çıkan olaylar takvimde olduğu gibi tamamen eşdeğer tutularak, kronolojiye göre sıralandığında a, b, c, d, e, f, g, h şeklinde bir dizi ortaya çıksın. Tarihçi diziyi anlatıya dönüştürürken bu olayların kimilerine hikâyede kilit roller atayarak veya diğer olayların nedeni şeklinde sunarak, bazılarını da tümden eleyerek diziyi A, b, C, e, G, H haline getirebilir. Hatta kronolojik olarak sonradan olmuş bir olaydan daha önce bahsedip bundan önceki bir zamanda gerçekleşmiş, ancak daha önemsiz bir olaya geri dönüşle, farklı bir bağlamda sonradan değinebilir. Böylece sonuç olarak $A, C, b, G, e, H$ şeklinde bir sıralama ortaya çıkabilir. Bu gibi işlemler yoluyla, tarihçi belgelerden çıkarıp kronolojik düzene koyduğu ilintisiz bir dizi olayı, bir olay örgüsüne (plot) göre hikâyeleştirip (emplotment) anlatıya çevirebilir (White, 1985d: 92-93).

Ne var ki tarihçinin bunu yaparken başvurabileceği olay örgüsü türleri sınırsız değildir ve önünde seçenek olarak yalnız kendi kültürünün sağladığı ve aynı kültürden kurgu yazarlarının da kullandığı olay örgüleri bulunur. Böylece kökleri her toplumun, kültürün kurucu mitlerinde yatan muhtelif olay örgüleri, onun tarihsel deneyimlerini anlatıp anlamlandırmak için de kullanılmakta, bir nevi gerçek olayların testine tabi tutulmuş olmaktadır (White, 1987b: 44). Yalnız burada söz konusu olanın mecazi, sembolik bir işlem olduğunu belirtmek gerekir. Nasıl ki "sevgilim bir güldür" derken şairin kastettiği, sevgilisinin gül gibi beyaz veya kırmızı 
renkte ve dikenli olduğu değil de kendi kültüründe gülün sembolize ettiği özelliklere sahip olduğu ise, tarihçi de bir olaylar dizisini trajedi olarak hikâyeleştirdiğinde söz konusu olan onun trajedi formunda bir eser kaleme alması değil, eserinin içerdiği motif ve temalar ile olayların trajik bir niteliğe sahip olduğunu ima etmesidir. Bir başka deyişle, tarihçi belli bir olaylar dizisini okuyucularının kurgu edebiyattan aşina olduğu bir olay örgüsü türüne benzeterek bu diziye atfettiği anlamı kavramalarını sağlamış olmaktadır (White, 1985d: 88-92).

White, Northrop Frye'ı takip ederek Batı'da bu temel olay örgüsü türlerinin dört tane olduğunu belirtir: romans, trajedi, komedi ve satir. Sözgelimi eğer bir tarihçi anlatısını tarihsel öznelerin (şahsiyetler, kurumlar vb.) karşılarına çıkan zorlukları yenerek başarıya ulaştığı bir hikâye şeklinde biçimlendiriyorsa romans olay örgüsünü seçmiş olmaktadır. Şayet bu özneler tüm çabalarına rağmen tabi oldukları doğal, toplumsal vb. yasaların aşılamayacak yapısından dolayı başarısızlığa uğruyor ve kaderlerine razı oluyorlarsa tarihçinin seçtiği olay örgüsü trajedidir. Eğer farklı özneler arasındaki gerilim ve çelişkiler, en azından geçici bir süre belli bir uzlaşmaya varıyor ise komedi olay örgüsü söz konusudur. Nihayet, şayet olayların gelişimi diğer olay örgülerindeki gibi galibiyet, yenilgi veya uzlaşma türünden bir sonuca ulaşmıyor, öznelerin çabaları, önlerinde engel teşkil eden herhangi bir yasanın varlığı da söz konusu olmadığı halde akim kalıyor ve okurun beklentileri karşılanmıyorsa, bu da seçilen olay örgüsünün satir olduğu anlamına gelmektedir (White, 1985c: 58-62; White, 2014d: 6-10).

White, anlatıyı kendi kültürünün sunduğu temel olay örgüsü tiplerinden hangisine uyarlayarak anlatacağını seçmenin hayalgücüne dayalı, kurgusal bir eylem olduğuna dikkat çeker. Sözgelimi Fransız Devrimi, farklı tarihçilerin bakış açılarına göre bir romans, trajedi, komedi veya satir olarak anlatılabilir. Bu seçimde, tarihin kronoloji ve mantıki açıklama kısımlarının dışında kalan, hayalgücüne dayalı yönü ortaya çıkmaktadır. Bir olaylar dizisini komedi veya romans değil de trajedi olarak hikâyeleştirme kararının arkasında doğal veya mantıksal hiçbir zorunluluk yatmamaktadır. Çünkü hikâyeler yaşanmaz, yazılır; bulunmaz, anlatılır; "gerçek hikâye" diye bir şey yoktur. Gerçek olayları şu veya bu tür bir hikâye olarak anlatmak, onları mecazlaştırmaktır; tüm hikâyeler kurgudur (White, 1985d: 84-85; White, 1985e: 111; White, 1999a: 9; White, 1999b: 28-30). Nitekim 19. yüzyıl sonlarında hepsi de eş yetenek, bilgi ve beceride tarihçiler, aynı olaylar hakkında birbirine hiç benzemeyen ama aynı geçerlik ve tutarlılıkta, aralarında ancak estetik veya ahlaki gerekçelerle tercihte bulunulabilecek anlatılar ortaya koyduğunda, tüm bilimsellik iddialarına karşın tarihin bu 
kurgusal yanının inkâr edilemeyecek bir şekilde ortaya çıktığına işaret eder White (White, 1985f: 124-125; White, 2014d: 432-434).

White'a göre bir tarih eserinin kronolojisinin ve mantıki argüman kısmının ötesine geçen, onun bu ikisine indirgenemeyecek tarihsel özünü teşkil eden ve aslında ona anlamını katan da bu kritik hikâyeleştirme aşamasıdır. Her tarih anlatısı, aynı anda iki şeye işaret eder; birisi yüzeydeki tarihsel olaylar dizisine, diğeri ise bunların derindeki anlamına, yani tarihçinin olayların yorumu olarak o olaylara giydirdiği olay örgüsüne. Böylece okurlar da anlatı boyunca tarihçinin seçtiği olay örgüsüne özgü motiflerle karşılaştıkça bir noktada bunların Batı kültüründe trajedi, romans, komedi veya satirle ilişkilendirilen özellikleri taşıdığını anlayacak ve böylece tarihçinin bu olaylara atfettiği anlamı kavramış olacaklardır (White, 1985c: 58-59; White, 1985d: 86-89; White, 1985e: 106-110; White, 1987b: 43; White, 1999a: 8).

Olay örgüsü seçimindeki keyfilik üzerinde dururken White'ın kendisi gibi tarih anlatısı sorununa kafa yormuş Paul Ricoeur'den ayrıldığını ve tarihçinin hayalgücüne daha büyük bir inisiyatif tanıdığını da belirtmek gerekir. Ricoeur'e göre geçmişteki aktörler yaşamlarını anlamlı kılma çabasıyla onu kendi içinde tutarlı bir olay örgüsü oluşturacak şekilde, önden biçimlendirirler. Aynı zamanda bugünden geriye doğru bakıldığında da bu aktörlerin eylemleri, sonuçlarıyla birlikte ele alındığında belli bir takım olay örgülerine işaret ederler. Anlatısallık (narrativity) ve değişik türlerdeki olay örgüleri, dolayısıyla geçmişin kendisine içkindir Ricoeur'e göre. Tarihçi bunları yeniden canlandırmak ve kavramak istiyorsa yine anlatı formuna başvurmak zorundadır (White, 1987d: 173-179). Hâlbuki White tarihçilerin geçmiş olayların anlatısında sembolik anlam düzleminde de olsa zaten mevcut bir olay örgüsünü keşfetmediği, tersine salt kendi ahlaki ve estetik seçimleriyle üzerinde karar kıldıkları herhangi bir olay örgüsünü tarihi olaylara empoze ettiği kanısındadır.

\section{Kavramsal Mecazi Çerçeve ve "Tarihçinin Üslubu"}

White'a göre tarihyazımının kurgusal niteliği, olaylar dizisinin başının sonunun belirlenmesi ve olay örgüsüne sahip bir hikâyeye dönüştürülmesinden de daha derinlere uzanır. Öncelikle tarihçi, anlatısını oluşturmaya girişmeden önce tarihsel alandaki nesneleri, yani kişileri, kurumları, olayları vb. buna göre seçip tanımlamaktadır. Sözgelimi Gibbon, Roma'daki bir kilisenin merdivenlerinden Titus Forumu'nun harabelerine bakarken bir anda tüm Roma tarihinin barbarlık ve din yüzünden İmparatorluğun gerileyip çökmesi izleğine göre anlatılabileceğini kavramıştı. Daha sonra eserini yazmaya koyulduğunda da sözünü edeceği 
gerçek kişi, yer ve olayları; okuyucularının anlatıyı bir "gerileme ve çöküş" hikâyesi olarak tanıyıp anlamasına elverecek mecaz ve klişelere dönüştürmüştü (White, 2000: 403). Keza Marx da III. Napoleon'un iktidara gelişini incelediği Louis Bonaparte'ın 18 Brumaire'i eserinde, Fransız burjuvazisi ve işçi sınıfını tüm hikâyeyi bir fars olarak anlatmaya izin verecek şekilde betimlemişti (White, 2000: 394).

White'a göre tarihin nesneleri artık görünür, gözlemlenebilir olmadığı için her tarihçi öncelikle üzerinde işlem yapacağı tarihsel alanı ve üzerindeki objeleri, bunlar arasında geçerli olan ilişkileri kurgusal bir şekilde teşkil etmek (constitute), önden canlandırmak (prefigure) zorundadır. Bunu yaparken de kaçınılmaz olarak günlük iletişimde kullandığımız normal dilin sunduğu araçlardan yararlanacaktır. Çünkü tarih; matematik, fizik veya felsefe gibi anlamları açıkça tanımlanmış, üzerinde anlaşılmış özel bir teknik jargon kullanmamaktadır. Dolayısıyla geçmiş dünyadan kalma olduklarından bize yabancı gelen nesneleri, bildiğimiz şeylere benzeterek aşina kılmak ve anlamlandırmak için Giambattista Vico'nun normal dilin mecazları olarak sıraladığı metafor, metonimi, synecdoche ve ironiden yararlanmak durumdadır (White, 1985a: 5; White, 1985d: 94; White, 2014d: 429). Bu temel kavramsal modelleri kullanan tarihçi; tarihsel alandaki olaylar, kişiler, kurumlar vb. nesneler ile bunların aralarındaki ilişkileri, anlatısında gerekli işlevleri üstlenecek şekilde teşkil eder. Mecazlar arasından metaforda, "Sevgilim bir güldür" cümlesindeki gibi ayrı objeler arasındaki benzerlik ve farklılıklara odaklanılması söz konusudur. Metonimide, otuz gemiden bahsetmek için otuz yelken denmesinde olduğu gibi geminin ayırt edici bir parçası, bütüne işaret etmek için kullanılır. Burada bir parça, yani yelken, geminin geri kalan parçalarına göre öne çıkartılmış olmaktadır; çünkü gemiyi diğer taşıtlardan ayıran özelliği, yelkenidir. Böylece parçalardan bazılarının neden-sonuç bağlantısında olduğu gibi diğerlerine tabi kılındığı ve aralarında hiyerarşik ilişkilerin olduğu bir kavrayış ortaya çıkmaktadır. Synecdoche'ta ise ön planda olan, parçabütün ilişkisidir. Burada parça, bir mikrokozm-makrokozm ilişkisi içinde bütünü temsil eder; sözgelimi bir kişi hakkında "O koca bir yürek" ("He is all heart") dendiğinde, o kişinin kalbin belli bir kültürde özdeşleştirildiği merhamet, şefkat gibi özelliklere sahip olduğu anlatılmış olur. İronide ise bir şey söylenirken tam tersi ima edilir. Sözgelimi "He is all heart" cümlesi belli bir ses tonu ve yüz ifadesiyle söylendiğinde veya yazıda buna karşılık gelecek bir bağlama yerleştirildiğinde, görünürdeki anlamının tam tersini ifade eder. İronide böylece diğer mecaz 
türlerinin gerçekliği kavrama yeteneği de sorgulanmış olmaktadır (White, 1985c: 71-74; White, 2014d: 29-37).

White, tarihçinin içinde yaşadığı toplum ve kültürle paylaştığı bu kavramsal mecazi çerçevenin, salt tarihsel alanı ve üzerindeki nesneleri teşkil etmek, aralarındaki ilişkiler için bir model oluşturmak amacına hizmet etmekle kalmayıp yukarıda bahsettiğimiz olay örgüsü seçimini de etkilediğine işaret eder. Böylece romans olay örgüsünün seçimine temel olan; birbirinden ayrı ve farklı öğeler arasındaki benzerlik ve farklara odaklanması nedeniyle metafordur. Trajedi olay örgüsünün temelinde yatan; parçalar arasındaki nedensellik ilişkilerini vurgulaması ve dolayısıyla tarihsel öznelerin yenik düştüğü yasalardan söz etmeye müsait olması nedeniyle metonimidir. Komedi olay örgüsünün seçiminde etkili olan; parçaların bir araya gelerek toplamlarından daha büyük bir bütün oluşturması, bir nevi uzlaşmaya varması bakımından synecdoche'tur. Diğer olay örgülerinin yarattığı beklentileri boşa çıkaran satir olay örgüsünün seçiminde etkili olan da, öteki eğretilemelerin gerçeği açıklama yeteneğini sorguladığını gördüğümüz ironidir (White, 1985d: 94-95; White, 1985f: 128).

White, kavramsal mecazi çerçevenin, olayların gelişimini açıklamak için mantıki argümanlar kurarken de etkili olduğunu belirtir. Böylece argüman düzleminde, metafor, metonimi, synecdoche ve ironi eğretilemelerine sırasıyla formist (veya ideografik), mekanistik, organisist ve bağlamsalcı argüman kipleri karşılık gelmektedir. Metaforun yukarıda aktarılan özellikleri uyarınca, tarihçi formist argüman kipini kullanıyor ise tarihsel sahadaki unsurları, birbirlerinden tüm farklılıklarını ve çeşitliliklerini öne çıkartacak şekilde betimlemekle, onlara "büyüteç tutmakla" yetinir. Bir başka deyişle, tarih sahasında gözlenen muhtelif olay, birey, topluluk, kurum veya kavramların kendine has özelliklerini belirlemeye ve bunların çeşitliliğini ve özgünlüğünü ortaya koymaya yönelir. Buna karşılık, metoniminin temelinde yattığı mekanistik argüman tarzını kullanıyorsa bazı unsurların diğerlerine onların sonucu olarak tabi kılındığı nedensellik ilişkilerine odaklanır. Bir başka deyişle, tarihteki olaylara yön verdiğine inanılan kanunları belirlemeye ve tarihteki gelişmelerin bu kanunların işleyiş̧inin sonuçları olduğunu göstermeye çalışır. Synecdoche'un temelinde yattığı organisist argüman kipini kullanıyorsa tarihsel sahadaki muhtelif olay, birey, topluluk, kurum veya kavramların nasıl tarihsel bir süreç boyunca bir araya gelerek toplamlarından daha fazla bir şey olan devlet gibi bütünleri oluşturduğuna odaklanır. Tarihsel süreçlerin ilerlediği ara veya nihai hedefleri ortaya koymaya çalışır. Son olarak, ironiye karşılık gelen bağlamsalcı argüman kipini kullanıyorsa da 
diğer mecaz ve argümanların gerçekleri aşina kılıp anlamlandırma gücünü sorgular ve bu nedenle tarihsel olguları kendi dönemlerinin kısıtlı bağlamına oturtmakla yetinir. Yani incelediği olay, birey, topluluk, kurum veya kavramları açıklamak için bunların kendi zamanlarının diğer olgularıyla ilişkilerini ortaya koymaya, etraflarındaki sosyo-kültürel ortamla bağlarını tespit etmeye ve içinde yer aldıkları trendleri, "atmosferi" yeniden canlandırmaya yönelir (White, 1985c: 63-66; White, 2014d: 10-21).

White, 19. yüzyıl tarihçilerini incelerken yazdıkları metinlerin temelinde yatan mecaz, argüman kipi ve olay örgüsü çeşitleri bir araya geldiğinde, bu dönemdeki dört ana ideolojik pozisyondan birini de ima ettiğini belirtir: anarşizm, radikalizm, muhafazakarlık ve liberalizm. Böylece temel mecazi çerçeve olarak metaforu benimseyen, formist bir argüman kipi kullanan ve anlatısını romans olay örgüsüne uygun olarak biçimlendiren bir tarihçinin metni (tarihçinin şahsi ideolojik duruşuyla tam olarak örtüşmesi gerekmeden) anarşist bir siyasi pozisyonu ima edecektir. Çünkü metafor kavramsal çerçevesi birbirinden bağımsız unsurları öngörür, formist argüman kipi tarihsel alandaki bireysel ve kolektif öğeleri birbirlerinden farklarını vurgulayacak şekilde tanımlar ve romans da tarihsel öznelerin karşılarındaki güçlere galip geldiği bir anlatı çerçevesi sunar. Bunların işaret ettiği de devletin ve devlete tabiiyetin ortadan kalktığı, yerine ortak insaniyetin vurgulandığı bir siyasi düzendir. Benzeri şekilde, tarihi metonimik bir çerçeveden kavrayan, buna uygun olarak neden-sonuç ilişkilerine dayalı açıklamalara yönelen, tarihin işleyişinin tabi olduğu yasaları bulmaya yönelen ve bu doğrultuda söz konusu yasaların baskın geldiği trajedi türü olay örgüsünü seçen tarihçinin anlatısı, bu yasalara tabi mevcut toplumsal düzenin aynı yasalar uyarınca değişmek zorunda kalacağını öngören radikal bir siyaseti ima eder. Buna karşılık synecdoche'a, yani parça-bütün ilişkilerine dayalı, tedrici gelişmeyi öngören organisist bir açıklama kipini benimsemiş, çekişme içindeki öznelerin sonunda vardığı uzlaşmaları vurgulayan komedi tipindeki tarih anlatılarının muhafazakâr bir ideolojik imaya sahip olması beklenir. Nihayet mecazi çerçeve olarak ironiyi benimsemiş, mekanistik ve organisist argüman kiplerinin genellemeci, bütünleştirmeci yaklaşımlarını paylaşmayıp inceleme objesini hemen etrafındaki bağlamla açıklamakla yetinen, ancak tarihsel öznelerin çabalarının romansın aksine bir şey değiştirmediği satir tipi olay örgüsünü tercih eden bir tarihçinin anlatısı da, anarşist/radikal dönüşümlere veya muhafazakârlığa yanaşmayan, şüpheci, ilerlemeyi uzak geleceğe atan liberal bir ideolojik duruşu ima edecektir (White, 1985c: 66-68; White, 2014d: 21-28). 
Böylece White'a göre tarihçilerin kullandığı argüman kipleri, olay örgüleri ve ideolojik imalar ile bunların temelinde yatan kavramsal mecazi çerçeveler arasında kimi seçici yakınlıklar (elective affinities) mevcuttur. Bu yakınlıklar Tablo 1'de özetlenmektedir:

Tablo 1

White'a Göre Seçici Yakınlıklar (Elective Affinities)

\begin{tabular}{cccc}
\hline Mecaz & Argüman & Olay Örgüsü & İdeolojik İma \\
\hline Metafor & Formist & Romantik & Anarşist \\
Metonimi & Mekanistik & Trajik & Radikal \\
Synecdoche & Organisist & Komik & Muhafazakâr \\
Ironi & Bağlamsalcı & Satirik & Liberal \\
\hline
\end{tabular}

Ancak White, tüm bu yakınlıkların determinist bir yapı taşımadığına da dikkat çeker; hatta incelediği Michelet, Ranke, Tocqueville ve Burckhardt gibi büyük tarihçilerin eserlerinin değerinin, birbiriyle tam olarak uyuşmayan mecaz, argüman kipi, olay örgüsü ve ideoloji kombinasyonları kullanmalarından kaynaklandığını vurgular. Sözgelimi Michelet'nin eserlerinin cazibesi, romantik bir olay örgüsüyle formist bir argümanı, beklenebileceği gibi anarşist değil liberal bir ideolojiyle harmanlamasından kaynaklanıyordu. Burckardt da şahsen bir liberal olmasına rağmen metninin ideolojik iması tablodan beklenebileceği gibi liberal değil muhafazakâr, hatta gericiydi. Bu yüzyıldaki tüm büyük tarihçilerin metinleri, bu tür gerilimli kombinasyonlar içermiştir White'a göre. Üstelik aralarından Tocqueville gibi bazıları, konularına uygulanabilecek alternatif kombinasyonların da farkında olmuş, bu alternatiflerden bazılarını denemiş, Ankersmit'in deyişiyle aralarındaki "çatlaklardan" geride yatan karmaşık tarihsel gerçekliğe ulaşmaya çalışmışlardır. White, farklı kombinasyonlara karşı sergilenen bu duyarlılığın 19. yüzyılda tarih kurumsallaşıp "bilimselleşince" ve anlatı olayların anlamını bir kez kavradıktan sonra bunu okuyuculara aktarırken kullanılacak bir araçtan ibaret görülmeye başlanınca kaybedildiğini vurgular. Bundan sonra gelen sıradan tarihçiler, söz konusu seçici yakınlıkların tuzağına düşerek alternatif kombinasyonların farkında varamamış ve sadece tablodaki satırlara karşılık gelen, en belli kombinasyonları kullanmışlardır. Bu da tarihsel 
gerçekliğin karmaşıklığının hakkını verememelerine, onu haddinden fazla basitleştirip gerçekte olmayan bir ahenk ve iç tutarlılıkla donatarak tek bir "doğru hikâye" şekilde betimlemelerine yol açmıştır White'a göre. (White, 1985c: 69-71; White, 1985f: 127, 129-30; White, 2014d: 2829; Ankersmit, 1998: 187-88).

\section{Kurgu Olarak Tarih Anlatısı ve Gerçeklik İçeriği}

Buraya kadar kurgusal işlemlerin tarihsel alandaki nesnelerin teşkil edilmesinden olay örgüsü, argüman kipi ve ideolojik imanın seçimine kadar tarih anlatısının oluşumunda ne kadar önemli bir rol oynadığını gördük. Peki, tüm bunlar White'ın tarih ile kurgu arasında hiçbir ayrımda bulunmadığı, tarih anlatısının gerçekliğe ulaşma iddiasını reddettiği, tavizsiz bir rölativizmle tarihçilerin çatışan yorumlarından hangisinin gerçekliği daha iyi yansıttığını değerlendirmek yerine bunları salt söz konusu seçimlerin bir fonksiyonu olarak gördüğü anlamına mı gelmektedir? Bu noktada hemen vurgulamak gerekir ki tarih ile kurgu arasındaki farklılıkları reddetmez White; tarihsel gerçekliğin varlığını ya da tarihçilerin belgeler ve diğer kaynakları kullanarak gerçeğe ulaşma şanslarını yadsımak gibi bir niyeti olmadığını açıkça belirtir. İşaret ettiği gibi, tarihçiler yalnızca tarihsel nitelikte, yani belli bir zaman ve yerde gözlemlenmiş bulunan olaylarla ilgilenirken kurgu edebiyat yazarları bu tür olayların yanısıra hayali olaylarla da ilgilenirler. Tarihçilerin kullandığı belgeler de geçmişten kalmış, sahici olaylardan bahseden kayıtlardır ve tarihçi bunların sunduğu verilere sadık olarak çalışmak durumundadır. Bu verilere çağın bilimsel kabul edilen metotlarını uygulayarak onları bilgiye çevirmesi mümkündür. Keza tarihçiler olayların kronolojisini belirledikten sonra şayet bir olay diğerinden sonra geliyorsa onun daha önce gerçekleştiğini de söyleyememektedirler (White, 1987a: 4-5; White, 1985f: 121; White, 1999a: 2).

Bu duruşuyla tutarlı olarak, White tarih anlatısını mitten farklı olmadığı gerekçesiyle eleştiren ve kendisinin aksine gerçekliğe erişme iddiasını sorgulayan Barthes ve Levi-Strauss gibi düşünürler ile Annales okulu tarihçilerine de karşı çıkar. Tarih anlatısı, tıpkı mit gibi geçmişteki olaylara bir başlayıp gelişmişlik ve bitmişlik havası, bir iç uyumu ve tutarlılık sağlıyorsa bunun nedeninin tarihin mitik bir karakterde olmasından değil, tarihin de mitin de dilin sunduğu imkân ve araçları kullanmalarından ileri geldiğini belirtir. Anlatıyı, dilin sunduğu mecaz seçenekleri arasından özellikle synecdoche'un hâkim olduğu bir söylem türü olarak tanımlar; çünkü bir zaman aralığına saçılmış bulunan öğeler (bireyler, kurumlar, olaylar), anlatıda toplamlarından daha büyük bir bütünün parçaları olarak bir araya getirilmektedirler. 
Bu da nasıl edebiyatta romanlar, tiyatro oyunları ve baladlar yazarken işe yarıyorsa tarihte de sürekliklerden, geçişlerden, bütünlüklerden söz ederken işe yaramaktadır. Synecdoche mecazının temelinde yattığı bir söylem türü olarak anlatıdan faydalanılmasının, dilin sunduğu diğer söylem biçimlerinden faydalanılması kadar meşru olduğuna işaret eder White. Dolayısıyla tarihin geçmiş olayları anlatıya dönüştürürken mitle birlikte dilin ortak araçlarından yararlanması, mitten farklı olarak belgelerde iz bırakmış gerçek olaylardan yola çıkmasının ona sağladığı gerçeklik payına halel getirmemektedir White'a göre (White, 1999a: 21-22). Aynı saptama olay örgüleri için de geçerlidir. Tarihçinin anlatısında gerçek olayları anlamlandırmak için kullandığı olay örgüleri her ne kadar içinde yetiştiği toplum ve kültürün mitlerinde ortaya çıkmış ve en arı ve gelişkin hallerini kurgu edebiyatta bulmuşlarsa da bu durum onları kurgudan ibaret saymak ve anlatının gerçeklik iddiasını reddetmek için yeterli bir neden değildir White'a göre. Çünkü tarih, mit ve kurgu edebiyatın ortak olarak paylaştığı olay örgüleri, aslında içinden çıktıkları toplum ve kültürün tarihsel deneyimlerinden damıtılmıştır; tarihçinin yaptığı ise bunları gerçek olaylara uygulayarak bilgi üretmektir. (White, 1987b: 44-45).

White böylece tarihin mit ve kurgu edebiyattan farklı olduğunu teslim etmesine karşın tarih anlatılarında kurgunun, hayalgücünün payını vurgulamakta ısrar eder. Öncelikle, işaret ettiği gibi tarihçinin belgelerden yola çıkarak geçmişteki insanların zihinlerine nüfuz etmesi, kendisininkinden tamamıyla farklı inanç ve değerlere sahip bu kişilerin amaç ve motivasyonlarını kavraması, o zamanın dünyasını zihninde canlandırması, yani geçmişe "empati"yle yaklaşması gerektiği, tarihi bilim olarak gören tarihçilerin de kabul ettiği bir gerçektir. Böylece geleneksel tarihçilik anlayışı dâhilinde de hayalgücüne geçmiş hakikatleri kavrama işinde önemli bir rol biçilmiş olmaktadır (White, 1987c: 67). Ayrıca tarih çalışmasının mantıki argüman ve analiz safhasında bile salt mantıkla açıklanamayacak seçimlerin yapılması söz konusudur. Nitekim, en düz mantık cümlesinde dahi kurgusal bir seçim olduğuna işaret eder White; "tüm insanlar ölümlüdür" tümel önermesinden "Sokrates de insandır" tikel önermesine ilerlerken başka biri değil de Sokrates üzerinde karar kılınması, mantıkla açıklanamayacak mecazi bir işlemdir (White, 1985a: 3). Ayıca tarihçi olaylar, kişiler ve kurumlar gibi olgular hakkında arşivlerden ve diğer kaynaklardan çıkmış verileri kullansa bile bu olgular geçmişte kaldığı, artık göz önünde olmadığı için onları hayalgücünün, kurgunun, gördüğümüz gibi mecazların önemli bir rol oynadığı bir süreç ile yeniden canlandırmak, teşkil ve tarif etmek zorundadır (Domanska, 2008: 16). Kaldı ki tarih, müspet ve sosyal bilimler gibi deneyler veya 
saha araştırmaları yürütemez. Dolayısıyla açıklamaya giriştiği tarihsel gerçekler de tarihsel olaylarla bir değildir. Geçmişten kalma belgelerde dile getiren olaylar, ancak tarihçi tarafından anlatısı için seçtiği olay örgüsüne kilit veya ikincil önemde bir öğe olarak eklemlenebilecek şekilde tanımlandıktan sonra, yani bir hikâyenin öğeleri olarak işlem görebilecekleri kanıtlanınca tarihsel gerçeklik statüsüne yükselirler. Çünkü tarihsel gerçek, "tarif edilen bir olay"dır ve tarihte gerçekleşmiş olayların tersine kavramsal veya mecazi olarak zihinde inşa edildiği için yalnız dil, düşünce ve söylem düzeyinde var olur (White, 2000: 397; White, 2014a: 45, 52-53). Üstelik gerçekliğin bir tarih anlatısı şeklinde temsili, nihayetinde tarihsel olaylara dayansa da konusunu mecburen kurgusallaştırıp estetize etmekte ve göreceleştirmekte; olayları, kişileri, yerleri ve süreçleri, edebi anlatılarda karşılaşılan türden mecazlara çevirmektedir (White, 2000: 405; White, 2014c: 80-81).

Bu nedenlerle White'a göre tarihçi mantıki argümanlara dayalı açıklamalardan ziyade yorumlama ve anlamlandırma yoluyla bilgi üretir ve bu bilgi de modern bilimlerin ürettiği bilginin kesinlik ve denenebilirliğine sahip olmamakla birlikte insani şeylerin doğasıyla ilgili içgörülerden oluşan bir bilgidir. Tarihçi anlamlandırma eylemi çerçevesinde dilin sağladığı temel mecazlara başvurarak ve olay örgülerini kendi kültürünün sağladığı olay örgüsü çeşitlerinden birine oturtarak yabancı bir geçmişi aşina kılar ve böylece okuyucularının onu anlayıp kavramasına yardımcı olur. Yani tarih metni aynı edebiyat anlatılarında olduğu gibi, ispatlar getirmekten ziyade ibret ve yorum yoluyla, alegorideki gibi doğrudan söylediğinin ötesinde şeylere işaret etmek suretiyle içgörü sağlar. Bu nedenledir ki tarihyazımının büyük klasikleri belli bir soruna eğilen bilimsel eserlerden beklenebileceği gibi nihai bir çözüm getirecekleri yerde tam tersine daha fazla araştırma ve yorum için ilham kaynağı vazifesi görmüşlerdir. En önemlisi de, yine aynı nedenle anlatı, tarihsel söylemin temel özelliği, tipik ürünüdür; onun olmadığı yerde, diğer söylem türlerinden ayrı bir tarihsel söylemin varlığından bahsetmek mümkün değildir (White, 1981: 796; White, 1985a: 23; White, 1987b: 43-44; White, 1987c: 60; White, 1999a: 2-7; White, 2014b: 63-65). Nitekim White'a göre 1980'lerde tarihyazımında gerçekleşen "anlatıya dönüş" de tarihçilerin tarihsel olguları ele alırken bilimselden ziyade edebi nitelikli bir yazının gerekli olduğunu fark etmelerinden kaynaklanmıştır. Böylece 19. yüzyıldan beri süren egemenliğine karşın tarihi gerçek bir bilime dönüştürmekte başarısız olmuş bir "bilimsel tarihçilik" anlayışının ve onun kesinlik ve açıklığa, 
kavramsallaştırma ve argümana verdiği ağırlığın yerini, tekrar mecazlar ve hikâyeleştirmeye dönüş almıştır (White, 2000: 395).

Bu nedenle White'a göre tarih anlatısının temelinde yatan derin kurgusallık; belgelerin tanıklık ettiği gerçek olaylara dayandığı bir yana bırakılsa dahi onun "uydurma" olduğunu göstermez. 19. yüzyılda tarihin kurumsallaşarak bilimsellik iddiasını benimsemesinin ardından, romantik sanatçılar bilimden korktukları, bilim adamları da sanattan bihaber oldukları için tarihin gerçeklerle ilgili, kurgu edebiyatın ise "hayali," "uydurma" olduğu, dolayısıyla gerçekliği anlamaya yardımcı olmaktan ziyade engel teşkil ettiği anlayışı yerleşmişti. Profesyonel tarihçiliğin duayeni Ranke'nin ihtar ettiği gibi bu yüzden ikisi asla karıştırılmamalı, tarih yazarken her türlü kurgu tekniğinden uzak durulmalıydı (White, 1985b: 28-29; White, 1985f: 123-124; White, 2005: 149-150). Oysa tümüyle kurgu olan edebiyatın da geçmişteki toplumsal ve insani gerçeklik hakkında bize bir şey söylemediğini, doğru bilgi vermediğini öne sürmenin imkânsızlığına işaret eder White. Bu bakımdan tarih anlatısıyla edebiyat anlatısı arasındaki paralelliklere dikkat çeker. Her ikisinde de ilk bakışta sorunlu ve esrarengiz görünen bir şey, bilincin mecazi stratejileri yoluyla tanıdık bir yüz kazandırılarak anlamlandırılmaktadır; her ne kadar edebiyatta bu dünya hayali, tarihte gerçek ise de anlamlandırma şekli birdir. Keza, nasıl ki romancılar hayalgücü ürünü olay ve kişileri düzenli, tutarlı bir dünyayı temsil edecek şekilde bir araya getiriyorlarsa tarihçiler de tarihsel kayıtlardan çıkardıkları gerçeklik fragmanlarını benzeri şekilde, aynı mecaz ve stratejileri kullanarak kavranabilir, uyumlu bir bütün haline getirmektedirler (White, 1985d: 98-99; White, 1985f: 125; White, 1999a: 13; White, 2014b: 68-69). Ayrıca her ne kadar edebi söylem hayali, tarihsel söylem gerçek olaylara atıfta bulunuyorsa da ikisinin de biçimiyle yorumsal içeriğini birbirinden ayırmak olanaksızdır; anlatılanlara verilen belli bir biçim, onların belli biçimde yorumlanması anlamına da gelmektedir (White, 1999a: 6). Her iki tür anlatıda da hem bir iç ahenk ve tutarlılığa ulaşma, hem de gerçekliğin bir imgesini teşkil etme amacı söz konusudur. Kurgu edebiyat salt bu iç ahengi sayesinde değil, hayali olay ve insanlar vasıtasıyla da olsa gerçekliğe karşılık geldiği, bize geçmiş insan ve toplumlar hakkında değerli içgörüler sağladığı için de değerlidir. Aynı şekilde tarih anlatıları da gerçeklere işaret etmekle beraber kurgulama yoluyla, tarihçinin yaratıcı, biçimlendirici dil kabiliyeti sayesinde ulaşılan sanatkârane iç tutarlılık ve ahenkleri için de değerlidir. Herodotos ve Tacitus'tan Gibbon, Tocqueville ve Burckhardt'a bilgi ve açıklamaları itibariyle aşılmış bulunan tarih anlatılarının bugün klasik olarak hala değer taşıması ve 
okunması, akademik tarihçilik için güncel olmaktan çıkmış tarih kitapların "sanata yeniden doğması" da kurgu edebiyatla taşıdığı tüm bu ortak özelliklerden dolayıdır White'a göre (White, 1985e: 118; White, 1985f: 121-22; White, 1987d: 180-81; White, 1999a: 5-6).

Rölativizm bağlamında ise, tarihçilerin muhtelif mecazlar, argüman kipleri ve olay örgülerini harmanlayarak kurguladıkları alternatif anlatıların ille de birbirini dışlayıcı değil, tamamlayıcı olduğuna işaret eder White. Dil geçmişi anlatmak için ne kadar farklı imkânlar; mecazlar, argüman kipleri ve olay örgüleri arasında ne kadar çok olası kombinasyonlar sunuyorsa hepsi denenmeli, tarihsel gerçekliğin farklı yüzlerine ulaşılmalıdır; hakikatin kavranmasında mesafe kat edilmesi, ancak tüm bu farklı versiyonların bir araya getirilmesiyle mümkün olacaktır. Çünkü gerçeklik son derece karmaşıktır ve tek bir "doğru hikâye"ye indirgenemez (White, 1985e: 117-18; Rogne, 2009: 74). Bu bakımdan tarihçileri, izlenimci ressamlara benzetir White. İzlenimci ressam, manzaranın tümünü bir tabloda tanımlamaya çalışmaz; değişik açılardan, değişik anlarda aynı manzaradan farklı kesitler sunar. Başka izlenimci ressamlar da yine aynı manzaranın farklı tablolarını yapabilirler, iki eş yetenekte ressamın tablolarından birinin diğerinden daha "doğru" olduğunu söylemek için bir neden yoktur. Aynı manzaranın ne kadar çok izlenimci tablosunu görürsek onun hakkında o kadar iyi bir fikir edinmiş oluruz. Benzeri şekilde, tarihçiler de belli bir konuyu değişik ana mecazlardan yola çıkarak inceleyebilirler. Bu mecaz inceledikleri konunun belli özelliklerini filtrelerken başka belli özelliklerini de çok daha keskin bir şekilde ön plana çıkartacak ve daha önce fark edilemeyen noktaların keşfini sağlayabilecektir. Sözgelimi Burckhardt, Rönesansı "bireycilik" ana mecazının merceğinden incelediğinde, bu dönem hakkında daha önce kimsenin fark edemediği bir takım tespitlerde bulunabilmiştir. Tarihçinin dayandığı bu ana mecaz ne kadar zengin ve çok boyutluysa incelediği konu hakkında o kadar yeni içgörüler sağlayacaktır. Bu şekilde bir mecazın tüm imkânlarını tükettikten sonra da başkalarını deneyebilecektir. Böylece modern bir bilim insanının değişik hipotezler deneyerek bir olguyu farklı açılardan incelediği gibi tarihçi de bir konuyu mümkün olduğunca çok ve farklı mecazların merceğinden inceleyerek onu kavrama yolunda önemli mesafe kat edebilecektir (White, 1985b: 44-47).

White'ın tüm bu saptamalarından çıkan önemli sonuç; dilin ve anlatının tarihsel bulguları ve onlar hakkındaki argümanları aktarmakta kullanılacak "saydam" vasıtalar olmayıp tarihsel alanı ve nesnelerini temel bir mecaza göre teşkil etme adımından olay ve süreçleri bir olay örgüsüne göre tanımlayıp anlamlandırma işlemine kadar kendi içeriklerini de beraberinde 
getirdikleridir. Yani tarihsel söylemi, her türlü mecaz ve kurgudan ayıklanıp bir dizi mantıki argüman şeklinde özetlendikten sonra hakikate uygunluğu ve mantıki geçerliliği sınanacak bir içerik, yani mazruf ile onun az çok becerili bir üslupla işlenmiş, ancak nihayetinde süsten ibaret dilsel zarfı olarak ayrıştırmak mümkün değildir. Her tür anlatı yazarı gibi tarih anlatısı yazarları da jargon değil günlük dili kullandıkları için o dilin ve kültürlerinin kendilerine sunduğu pek çok mecaz ve anlatı türü arasından seçme yapmakta, bunların sağladığı kodları çok katmanlı bir şekilde birbirine örmektedir. Ürettikleri metin, bu nedenle bilimsel metinlerin tersine ve tıpkı kurgu edebiyat metinlerinde olduğu gibi kısmen yazarın niyetlerinin de ötesine geçen anlam ve imalar içermektedir. Nasıl ki şiirin ses ve vezin yapısı düzyazıya çevrildiğinde kaybolacak anlamlar üretiyorsa tarih anlatısındaki motif, tema ve olay örgüleri de salt tarihçinin sunduğu bilgi ve argümanlar özetlendiğinde kaybolacak anlamlar, içerikler üretmektedir. White, bu söylediklerini Marx'ın Louis Buonaparte'ın 18 Brumaire'i eseriyle örnekler. Marx, anlatısını olaylar örgüsünün bir fars olduğunu ima edecek şekilde biçimlendirmiştir; ancak olayların neden trajedi veya komedi olarak değil de fars olarak temsil edilmesi gerektiği, gerçekler ile de mantık ile de açıklanamaz. Bu, yazarın tamamen kendi seçimi ve yargısını kullanarak olaylar örgüsünü mit ve edebiyatta da rastlanılan olay örgülerinden birine oturtmak suretiyle getirdiği bir yorumdur. Dolayısıyla salt Marx'ın anlatısının naklettiği olaylara ve mantıki argümanlarının tutarlıı̆̆ına odaklanır, anlatının bir bütün olarak "fars" karakteri taşıdığını zahiri bir özellik, bir süs sayarak gözardı edersek içerdiği can alıcı mesajı gözden kaçırmış oluruz. Bu bakımdan anlatının kurgu eserlere de özgü olay örgüsü tiplerinden birini benimseyerek esere kattığı yorum içeriği, metinden çıkartılıp özetlenebilecek bilgi ve argüman içeriği kadar, hatta daha önemlidir. Anlatı, asla bu bilgi ve argümanların aktarılmasında kullanılacak boş bir kaptan ibaret değildir (White, 1987b: 41-48; White, 1999a: 4-5; White, 1999b: 27-28; White, 2014c: 93).

White'a göre, bir biçim olarak tarih anlatısının beraberinde getirdiği bu kurgusal içeriğin farkına varılması, üç işe yarayacaktır. İlkin, tarihçileri kendi söylemlerindeki kurgusal ve dolayısıyla ideolojik öğelere karşı daha duyarlı kılacaktır. Şimdiki haliyle tarihçilerin gerçekçilikten uzak bir nesnellik iddiası taşıdıklarına ve yalnızca yorumları kendileriyle uyuşmayan tarihçilerin eserlerindeki ideolojiyi gördüklerine dikkat çeker White. Başkalarıyla uyuşmamalarının nedenini onların "ideolojik çarpıtmalarında" aramakta, ama kendi anlatılarındaki ideolojik içeriği görememektedirler. Hâlbuki kendi anlatılarındaki kurgu payının 
farkına varsalar, "tarafsızlık" ve "gerçekliği olduğu gibi yansıtma" iddialarını öne sürerken daha ihtiyatlı olacaklardır. White'a göre tarih anlatılarındaki kurgusal öğenin farkına varmak aynı zamanda tarih eğitiminde de faydalı olacaktır, çünkü bugün itibariyle klasikleşmiş büyük tarihçileri kalıcı kılanın kurgulamada gösterdikleri ustalık olduğunun bilinmesi, danışmanı gibi yazmaya özenip de bir türlü başaramayan ve neden başaramadığını da anlayamayan tarihçi adaylarına ışık tutacak; tarihyazımının tam olarak ne olduğunun onlara daha iyi öğretilebilmesini sağlayacaktır. Son ama belki en önemli olarak da tarih anlatılarındaki kurgusallığın kabul edilmesi, günümüz tarihyazımını kendi yöntemlerine karşı bu eleştirel farkındalıktan yoksun tutumundan kurtaracak; bilimsellik ve nesnellik iddiaları yüzünden kendini mahrum bıraktığı, ancak en büyük güç ve yenilenme kaynağını oluşturan edebi hayalgücünü yeniden keşfetmesini sağlayacaktır. Bu sayede tarihin gerçek anlamda bir disiplin haline gelmesine izin verecek bir tarih teorisinin kurulması ve tarihçilerin modern sosyal bilimciler ve sanatçılardan gelen eleştirileri daha iyi göğüslemesi mümkün olacaktır (White, 1985d: 99). Çünkü sonraki bölümde göreceğimiz gibi günümüz tarihçiliğinin hâlâ bu farkındalıktan yoksun olmasının, gerek modern bilim ve sanata karşı statüsü, gerek de siyasitoplumsal işlevleri bakımından önemli sorunlara yol açtığı kanısındadır White.

\section{Geleneksel Anlatı Sorunu}

"Tarihin Yükü" adlı makalesinde White, tarihçilerin kendilerini sistematik olmaktan uzak metotları ve kesinlikten yoksun sosyo-psikolojik varsayımları yüzünden eleştiren sosyal bilimcilere karşı tarihin zaten bir çeşit sanat olduğu ve analitik metotlar kadar içgüdüye de dayandığı; kullandıkları anlatı tekniklerinin nuh nebiden kalma olduğu eleştirisinde bulunan edebiyatçılara karşı da tarihin bir çeşit bilim olduğu ve tarihsel verilerin öyle sanatçıların alışık olduğu gibi serbestçe biçimlendirmeye elvermediği savlarıyla karşılık vererek kaçak güreştiklerini söyler. Bu tutumun sonucunda da 19. yüzyıl sonlarından kalma bir pozitivist bilim anlayışını, aynı yüzyılın ortalarından kalma bir romantik sanat anlayışıyla kaynaştırmanın ötesine geçememektedirler. Bu açıdan White, 19. yüzyılda şekillenmiş bilimsellik iddialı kurumsal tarihçiliğin, 19. yüzyılın realist romanlarına özgü anlatı anlayışını sürdürmesini uzun uzun eleştirir (White, 1985b: 27-44). Her ne kadar yukarıda gördüğümüz gibi tarih anlatılarının taşıdıkları güçlü kurgu öğesi ile tarihi gerçekler hakkında edebi anlatılar gibi önemli içgörüler sağlayabileceğini kabul etse de kariyerinin ilerleyen yıllarında geleneksel tarihçilikte kullanıldığı şekliyle anlatının olumsuz yönlerini giderek daha çok vurgular; bu bakımdan 
anlatıyı tarihsel öznelerin eylemlerine içkin gören ve peşinen olumlayan Ricoeur'den ayrılır (Partner, 1998: 168-69).

White'ın tarih anlatısına başlıca itirazı; onun gerçekliği maskelemeye ve sosyal konformizmi sağlamaya dönük estetize edici yönüdür. Bu bakımdan Braudel gibi anlatının bizzat kendisinin ideoloji olduğu görüşündedir (Rogne, 2009: 67). Çünkü tarihçi anlatısını şekillendirirken gerçekliği indirgeyerek, kimi kısımlarını dışarıda bırakıp kimi kısımlarını ön plana çıkartarak, hikâyesini gördüğümüz gibi sosyo-politik bir merkezin ahlaki pozisyonuna göre başlangıç ve son noktalarıyla çerçeveleyerek, olayları muhafazakâr ve liberallerin hoşuna gidecek tedrici bir gelişme çizgisine göre aktararak, tarihsel kayıttaki boşlukları kurgu yoluyla doldurarak ve her şeye bir mantıkilik, anlaşılabilirlik görünümü vererek özellikle modern gerçekliğe karşılık gelmeyen, mitik karakterde bir tamamlanmışlık, bütünlük, tutarlılık havası, illüzyonu üretmektedir. Böylece tıpkı diğer anlatı yazarları gibi burjuva sınıfının psikolojik ihtiyaçlarını karşılamakta, gerçekliğin çıplak yüzüne maske geçirmekte, bu maskeyle o yüzden "koruduğu" okurlarını kurgulanmış bir dünyada yaşatmak suretiyle hem modern toplumlardaki acı verici yaşam koşullarına karşı teselli sağlamakta, hem de ulus-devletlerin uyumlu, sorumluluğunun bilincinde vatandaş tipinin inşasına hizmet etmektedir (White, 1987b: 36; White, 2014c: 93-94; Partner, 1998: 167; Paul, 2011: 113).

White bu bağlamda Schiller'in değindiği, tarihte "yüce olan" (sublime) karşısında tarih anlatısının durumuna ve bu durumun toplumsal sonuçlarına da değinir. Buradaki "yüce"yi White geçmişin anlamlandırılması zor veya imkânsız, dehşet ve şaşkınlığa sürükleyici yönlerini kast etmek için kullanmaktadır. Anlatının estetik olarak biçimlendirilmişliği ile ürettiği bütünlük, tutarlılık ve mantıkilik illüzyonu, tarihin bu anlamsız, dehşet ve şaşkınlığa sürükleyici yanlarının örtbas edilerek geçmişin ehlileştirilmesi sonucunu da doğurmaktadır White'a göre. 19. yüzyılın ilk yarısında yetişmiş Michelet ve Carlyle gibi büyük tarihçiler hâlâ tarihteki olayların bu yönüne karşı duyarlılıklarını korudukları halde tarihin kurumsallaşmasından sonra gerçekçi romanın anlatı tarzıyla yetinen tarihçiler, söz konusu perspektifi kaybetmişlerdir. Netice olarak geriye eski anlatı tarzlarından ileriye geçemediği için tarihi ehlileştiren, estetize eden, onu tamamıyla açıklanabilir bir şey olarak sunan akademik bir tarihçilik anlayışı kalmıştır. Oysa varoluşçu felsefeden derinlemesine etkilenmiş olan White'a göre geçmişin anlamsız, yabani, dehşetengiz yönü, her şeyi anlatı ve argümanlarıyla açıkladığı iddiasındaki bir tarih anlayışına kurban edilmeyip modern edebiyatın tekniklerinden de yararlanarak bütün 
çıplaklığıyla ortaya konsaydı, insanların bu anlamsızlık karşısında duydukları tepkiyle, kendi varlıklarını bizzat seçtikleri anlamla donatmak üzere harekete geçmeleri mümkün hale gelecekti. Geleneksel tarih anlatısı tarzlarına bağlı kalarak geçmişi tümüyle tutarlı, ahenkli, açıklanabilir bir şey olarak takdim eden akademik tarihçilik türleri ise, velev ki Marksist de olsalar, tarihyazımını ezilen veya direniş halindeki toplumsal grupların mücadelesi için bir ilham ve meşruiyet kaynağı olmaktan çıkartmakta, mevcut toplumsal statükonun devamına hizmet etmesini sağlamaktadırlar. Dolayısıyla 19. yüzyıl realist romanlarından devralınma bir anlatı anlayışıyla yetinmenin ağır siyasi ve toplumsal bedelleri de vardır White'a göre (White, 1987c: 68-82).

White geleneksel anlatının teşkil ettiği bu sorunların bir çözüm yolu olarak anlatılaştırmanın (narrativize), yani olanları bir başlangıç, orta ve son ile donatıp uyumlu ve estetize bir hikâye haline getirmenin karşısına sadece anlatmayı (narrate), yani birinci kişinin ağzından dünyadaki herhangi bir şey hakkında onu dramatize etmeden konuşmayı koyar (White, 1987c: 81; White, 2000: 399; Rogne, 2009: 68). Özellikle modern çağın olaylarını anlatan tarihçilerin, anlatılaştırma alışkanlığını terk ederek modern edebiyatın anlatma tekniklerine yönelmeleri gerektiğine işaret eder. Çünkü tarihte anlamlandırılmaya direnen, dehşet ve şaşkınlık uyandırıcı "yüce" yön, en büyük yoğunlukla ve dolayısıyla anlatıya aktarılması en zor olacak şekilde 20. yüzyılda gerçekleşen, eşi benzeri görülmemiş, White'ın tabiriyle "modernist olay" olarak adlandırılabilecek kimi olaylarda hissedilmektedir: Büyük Buhran, iki Dünya Savaşı, Yahudi Soykırımı, atom bombası, nüfus patlaması, kıtık, ekolojik çöküş tehlikesi vs. Tüm bu olaylar çeşitli sebeplerle geleneksel anlatılaştırmaya özellikle dirençli bir niteliktedir. Öncelikle, modern teknoloji sayesinde o zamana kadar görülmedik bir coğrafi çap ve yayılıma ulaşmış, görülmedik sayıda insanı etkilemişlerdir. Sonra modern kitle iletişim olanakları sayesinde her yönleriyle, tüm detaylarıyla belgelendiklerinden haklarında tek bir "doğru anlatı" sunulması için ilgili verilerin gerekli indirgemeye tabi tutulması son derece güçtür (bu bağlamda Claude Levi-Strauss'un “enformasyon azaldıkça anlama artar, enformasyon çoğaldıkça anlama azalır" tespitine gönderme yapar White). Ayrıca yakın geçmişte gerçekleştikleri ve hala duygusal etkilerini korudukları için bu tür olaylara tarihçiliğin gerektirdiği mesafeden bakılması da zordur. Nihayet, anlatı kendi sorumluluklarıyla davranan, özgür iradesiyle seçim yapan rasyonel öznelerin varlığını varsaydığı halde milyonlarca insanı ölüme gönderen modern diktatörlük düzenlerindeki özneler, bu varsayıma uymamaktadır. 
Dolayısıyla modernist olayların anlamlandırılması ve anlatılması için geleneksel anlatı yeterli gelmemektedir (White, 1999c: 70-74; White, 2014c: 80-81; Paul, 2011: 129-138).

Ancak tarihsel "yüce" gibi modernist olaylar bağlamında da anlatı yetersiz olmakla kalmayıp sakıncalıdır da. Çünkü Yahudi Soykırımı gibi olaylar geleneksel olay örgüleri kullanılarak klasik bir başlangıç-gelişme-son çizgisiyle, gerçekliğe karşılık gelmeyen bir iç ahenk ve tutarlıııkla donatılır, her şeyi görüp bilen, anlatı nesnesine uzak bir anlatıcının dilinden aktarılırlarsa, yaşananların korkunçluğunu ve anlamsızlığının örtme, onları estetize ederek gerçek özlerinin görülmesini engelleme tehlikesi ortaya çıkmaktadır. Sonuç olarak bu gibi olaylar normalleşecek, ehlileşecek, her kıssa gibi hisseleri çıkarıldıktan sonra tarihin tozlu raflarına kaldırılabileceklerdir. Bu da başı başına etik bir sorun teşkil edecektir. White bu tehlikelerden kaçınmak için Saul Friedländer'in Yahudi Soykırımı'nı konu alan The Years of Extermination adlı eserinde yaptığı gibi, James Joyce, Virginia Woolf, Primo Levi ve diğer modernist anlatı ustalarının anlatılaştırmadan anlatma tekniklerinden yararlanılabileceğine işaret eder. Bu bağlamda Roland Barthes'ın "geçişsiz yazı" kavramına atıfta bulunur (White, 1999c: 81; White, 2014c: 77-92). Barthes bu kavramı, geçişsiz fiil çatısından esinlenerek üretmiştir. Geçişli bir fiil yakmak veya yakılmak şeklinde, etken veya edilgen tarzda kullanılabilirken yanmak şeklinde, dönüşlü tarzda kullanıldığında geçişsiz hale gelmekte, "kendini yakmak" anlamına gelmektedir. Buna göre geleneksel, "geçişli" bir anlatıda, betimlediği dünyadaki bilmeye değer her şeyi bilen ve bildiğini de bilen, bu bilgileri de onlarla ilgili düşüncelerini de önemli bir çarpıtmaya maruz kalmadan aktarabilen, dünyaya yukarıdan, belli bir mesafeden bakıp hakkında ahlaki yargıda da bulunabilen bir özne, gördüklerini okurlarına da göstermek için yazmaktadır. Geçişsiz yazıda ise yazar yazmayı bizzat görmenin bir yoluna dönüştürmekte, yazarak kendini bulmakta ve kişisel deneyimlerini anlamlandırmaya çalışmaktadır. White'a göre ancak anlatıcı ile anlatılan, geçmiş ile şimdiki zaman, dış olaylar ile iç bilinç akışı, gerçek ile temsil arasındaki ayrımları kaldıran bu teknikler sayesindedir ki modernist olayları aktarmak mümkün olacaktır. Çünkü geçişsiz yazı bu gibi hayrete düşürücü, inanılması zor olayların anlamlandırılmasının önündeki engelleri görmezden gelmeyip olayların kendileri kadar temsilleriyle ilgili sorunlarla da açıkça yüzleşmekte, bir yandan geçmişte olanlardan bahsederken diğer yandan da halen travmatik bir geçmişin anlatılması ve yorumlanmasında karşılaşılan güçlükler üzerinde durmaktadır (White, 1999b: 37-42; White, 2014a: 57; White, 2014c: 78; Paul, 2011: 134-137). 


\section{Sonuç}

Bu makalede, White'ın tarih anlatısı konusunda kapsamlı olduğu kadar karmaşık ve konu üzerine yazdığı yarım asır boyunca değişip geliştiği için tümüyle tutarlı da olmayan teori ve analizlerini mümkün olduğu kadar anlaşılır bir şekilde özetleyip açıklamaya gayret ettik. Bunların değerlendirilip eleştirilmesi, ayrı bir çalışmanın konusudur. Getirilebilecek tüm eleştirilerden bağımsız olarak, bu noktada White'ın saptamalarının tarih anlatılarındaki kurgusallığın farkına varmak ve anlatının bulgularımızı ve analizlerimizi aktarmakta rahatça kullanabileceğimiz saydam bir iletişim aracı olduğunu varsaymamak açısından taşıdığı öneme işaret etmek yeterli olacaktır. Çalışmanın bu son kısmında, White'ın yeterince irdelemediği, ancak benzeri bir yaklaşımla incelenmeleri durumunda değerli gözlemler sağlayabilecek üç konuya işaret edeceğiz.

Illkin, doktorasını aslında Ortaçağ tarihi alanında vermiş olan White'ın ilk bölümde değindiğimiz, değişik formlarda üç Ortaçağ tarih eseri üzerinde durduğu son derece ilginç makalesi dışında 18. yüzyıl ve daha öncesinin tarihyazımlarına eğilmediği görülüyor. Hâlbuki White'ın metodolojisi diğer dönemlerin, Eski, Orta ve Yeniçağın tarihyazımlarına da pekâlâ uygulanabilir ve değerli sonuçlar üretebilir. Nitekim Ortaçağ tarihyazımı örneklerini dilsel dönüşü de göz önünde tutarak inceleyen Nancy Partner, değerli eserler ortaya koymuştur (bkz. Partner, 1977). Bunun gibi, White'ın teorilerinin farklı çağların yanısıra başka coğrafyaların tarihyazımlarına da uygulanması, ilginç karşılaştırmalar sağlayabilir. Oysa White, Marilyn Waldman'ın (1981: 785-786) da işaret ettiği gibi Avrupa merkezci bir bakışa sahiptir ve tüm çalışmalarında Batı tarihçiliğini incelemiştir. Waldman'ın İslam tarihçiliği konusunda dediklerinden esinle, şu tür sorular da irdelenebilir: Trajedi ve komedi gibi olay örgüsü türleri örneğin klasik İslam medeniyetinde olmadığına göre İslam ülkelerindeki tarihçiler takvim ve vakayiname formlarının dışına çıktıklarında ne tür olay örgüleri kullanmışlardır? Yine klasik İslam medeniyetinde gelişmiş bir sosyo-politik merkez olması, buralarda takvim ve vakayiname türlerinin devam eden itibarıyla çelişmemekte midir? Diğer kültürlerde yetişmiş tarihçilerin tarihsel alanı betimlerken başvurdukları mecazlar, Batı tarihçiliğinde kullanılan metafor, metonimi, synecdoche ve ironi ile ne açılardan benzeşmekte, ne açılardan onlardan ayrılmaktadır? Siyasi imaları yönünden farklı medeniyetlerin tarih anlatıları nasıl karşılaştırılabilir? Tarihteki "yüce"nin anlamsız, dehşetengiz, şaşırtıcı yüzünü ve bu 
kategorideki modernist olayları aksettirmek için diğer kültürlerdeki tarihçilerin önünde çağdaş Batı anlatıları dışında ne gibi alternatifler vardır?

White'ın yaklaşımının geliştirilebileceği başka bir konu da tarihçiliğin araştırma safhasıdır. White profesyonel tarihçiler için can alıcı önemdeki bu aşamaya tarihyazımı hakkındaki hacimli veriminde hemen hiç değinmez, kendisinin de belirttiği gibi yalnızca toplumsal dolaşıma girip okuyuculara ulaşan son ürünün, tarih eserinin kompozisyonuna odaklanır (Jenkins, 2016: 75). Araştırma safhası hakkındaysa tarihçilerin tıpkı bir gazeteci veya dedektif gibi karanlıkta kalmış veya bırakılmış bilgileri gün yüzüne çıkartıp geçmiş hakkındaki bir hakikati keşfetmeye çalıştıklarını söylemekle yetinir; yazarın kurgusal işlemleri, ancak bunu takip eden, yazılı metnin tamamlanmasına uzanan sürede yoğunlaşır ona göre (White, 1999a: 8). Ancak başka bir yerde de tarihçiliğin bu iki aşamasını biri bitip diğeri başlayan iki safha olarak hiçbir zaman kesin çizgilerle ayırmadığını vurgular; tarihçilerin önce tüm araştırmalarını tamamlayıp ancak onsan sonra yazma aşamasına geçmediklerini, araştırma ve yazmanın baştan itibaren iç içe ilerleyen süreçler olduğunu belirtir (White, 2014d: xxvii). Bu bağlamda, kurgulamaya özgü işlemlerin araştırmaya nasıl etki ettiği sorusu da gündeme gelmektedir. White, yukarıda gördüğümüz gibi tarihçinin tarihsel alandaki nesneleri ve aralarındaki ilişkileri teşkil eder ve tanımlarken belli bir mecazi çerçeveden yararlandığını, bu mecazla uyumlu bir olay örgüsü ve argüman kipi seçtiğini, tarihsel olayları da anlatısının olay örgüsünde oynayacakları rollere göre seçip betimlediğini anlatır. Yani tarihçinin bulgularını anlatıya dönüştürürken kullandığı stratejilerin, daha elde edilmiş bulguların seçimi ve tanımlanması aşamasında da etkili olduğunu kabul eder. Peki bu stratejiler, White'ın yazmayla baş başa gittiğini söylediği araştırma üzerinde de benzeri bir etkiye sahip olabilirler mi? Tarihçinin verileri araştırırken zihninde yavaş yavaş şekillenmeye başlayan mecaz, argüman kipi, olay örgüsü ve ideolojik ima; kullanacağı belgeleri okuma ve ilgili verileri tespit etme şeklini de etkiliyor olabilir mi? Bu tür soruların irdelenmesi de bütün bir tarihyazımı sürecine daha geniş bir açıdan ışık tutabilecektir. 


\section{Kaynakça}

Ankersmit, F. (1998). Hayden White's appeal to the historians. History and Theory, 37 (2), s. 182-93.

Ankersmit, F. (2009). Narrative, an introduction. F. Ankersmit, E. Domańska ve H. Kellner (Ed.), Re-figuring Hayden White (s. 77-81). Stanford: Stanford University.

Domańska, E. (2008). A conversation with Hayden White. Rethinking History 12 (1), s. 3-21.

Domańska, E., Kellner, H. ve White, H. (1994). Hayden White: The image of self-presentation. Diacritics, 24 (1), s. 91-100.

Jenkins, K. (1998). A Conversation with Hayden White. Literature \& History 7 (1), s. 68-82.

Partner, N. (1977). Serious entertainments: The writing of history in twelfth-century England. Chicago: University of Chicago.

Partner, N. (1998). Hayden White: The form of the content. History and Theory 37 (2), s. 16272.

Paul, H. (2011). Hayden White: The historical imagination. Cambridge: Polity.

Rogne, E. (2009). The aim of interpretation is to create perplexity in the face of the real: Hayden White in conversation with Erlend Rogne. History and Theory, 48, s. 63-75.

Waldman, M. R. (1981). "The otherwise unnoteworthy year 711": A reply to Hayden White. Critical Inquiry, 7 (4), s. 784-792.

White, H. (1981). The narrativization of real events. Critical Inquiry, 7 (4), s. 793-798.

White, H. (1985b). Introduction. The tropics of discourse: Essays in cultural criticism (s. 1-26). Baltimore: Johns Hopkins University.

White, H. (1985b). The burden of history. The tropics of discourse: Essays in cultural criticism (s. 27-50). Baltimore: Johns Hopkins University.

White, H. (1985c). Interpretation in history. The tropics of discourse: Essays in cultural criticism (s. 51-80). Baltimore: Johns Hopkins University. 
White, H. (1985d). The historical text as literary artifact. The tropics of discourse: Essays in cultural criticism (s. 81-100). Baltimore: Johns Hopkins University.

White, H. (1985e). Historicism, history, and the figurative imagination. The tropics of discourse: Essays in cultural criticism (s. 101-120). Baltimore: Johns Hopkins University.

White, H. (1985f). The fictions of factual representation. The tropics of discourse: Essays in cultural criticism (s. 121-134). Baltimore: Johns Hopkins University.

White, H. (1987a). The value of narrativity in the representation of reality. The content of the form: Narrative discourse and historical representation (s. 1-25). Baltimore: Johns Hopkins University.

White, H. (1987b). The question of narrative in contemporary historical theory. The content of the form: Narrative discourse and historical representation (s. 26-57). Baltimore: Johns Hopkins University.

White, H. (1987c). The politics of historical interpretation: Discipline and de-sublimation. The content of the form: Narrative discourse and historical representation (s. 58-82). Baltimore: Johns Hopkins University.

White, H. (1987d). The metaphysics of narrativity: Time and symbol in Ricoeur's philosophy of history. The content of the form: Narrative discourse and historical representation (s. 169-84). Baltimore: Johns Hopkins University.

White, H. (1999a). Literary theory and historical writing. Figural realism: Studies in the mimesis effect (s. 1-26). Baltimore: Johns Hopkins University.

White, H. (1999b). Historical emplotment and the problem of truth in historical representation. Figural realism: Studies in the mimesis effect (s. 27-42). Baltimore: Johns Hopkins University.

White, H. (1999c). The modernist event. Figural realism: Studies in the mimesis effect (s. 6686). Baltimore: Johns Hopkins University.

White, H. (2000). An old question raised again: Is historiography art or science? (Response to Iggers). Rethinking History: The Journal of Theory and Practice, 4 (3), s. 391-406.

White, H. (2005). Introduction: Historical fiction, fictional history, and historical reality. Rethinking History: The Journal of Theory and Practice, 9 (2-3), s. 147-57. 
White, H. (2014a). The historical event. The practical past (s. 41-62). Evanston, IL: Northwestern University.

White, H. (2014b). Contextualism and historical understanding. The practical past (s. 63-73). Evanston, IL: Northwestern University.

White, H. (2014c). Historical discourse and literary theory. The practical past (s. 75-96). Evanston, IL: Northwestern University.

White, H. (2014d). Metahistory: The historical imagination in $19^{\text {th }}$-century Europe. $40^{\text {th }}$ Anniversary Edition, Baltimore: Johns Hopkins University. 